\title{
A comparison of leather properties of skins from ten different South African sheep breeds
}

\author{
M.A. Snyman ${ }^{1}$ and C.A. Jackson-Moss ${ }^{2}$ \\ ${ }^{1}$ Grootfontein ADI, P/Bag X529, Middelburg, (EC), 5900 \\ ${ }^{2}$ International School of Tanning Technology, P.O. Box 2085, Grahamstown, 6140 \\ e-mail:Dier6@karoo1.agric.za
}

\section{Introduction}

Skins contribute significantly to the value of slaughter animals. It is therefore essential that the true value of the skins of different breeds is known to ensure that producers receive the optimum remuneration for their product. A project in which the tanning properties of skins of ten different South African woolled, mutton and dual purpose sheep breeds were evaluated, was done by Grootfontein Agricultural Development Institute, in cooperation with the Tannery Division of the Leather Industries Research Institute (LIRI) in Grahamstown.

\section{Material and Methods}

Skins of the following breeds of the extensive sheep grazing areas were evaluated at marketing age of the different breeds, namely Merino (wool), Afrino (mutton \& wool), Hair type Dorper (mutton), Wool type Dorper (mutton), Namaqua Afrikaner (fat tail mutton), Damara (fat tail mutton), Blackhead Persian (fat rump mutton), Speckled Persian (fat rump mutton) and Van Rooy sheep (fat tail mutton). Dormer sheep (mutton \& wool) were included in the trial as representative of the coarser wool breeds, in order to serve as a comparison for Afrino skins. Eight skins of each breed were evaluated. Two skins were processed with the wool on, and six were tanned through to nappa leather for final testing and visual evaluation. The following physical properties were evaluated on the nappa leather : Tensile strength, Extension at grain crack, Extension at grain break, Slit tear strength and the Lastometer test. These tests give an indication of the strength of the leather as well as the amount that the leather could be stretched before the upper grain layers crack, which will cause damage to the surface of the leather. After processing of the skins to undyed crust, the skins, with the exception of the Merino skins, were shaved down to a substance of $0.7-0.9 \mathrm{~mm}$. The Merino skins could not be properly shaved due to the ribbiness of the skins. After shaving, the skins were dyed and sampled in the butt region and physical tests carried out on the samples.

\section{Results and Discussion}

Wool on tanned skins:

The fleece of skins from Dorper and Namaqua Afrikaner sheep tends to become matted due to loose hair present in the fleece in the raw skin when tanned with the wool on. These skins can be combed out manually to achieve an acceptable appearance, however, it is rather time consuming. Skins from the other hairy breeds (Damara, Persian and Van Rooy), as well as the wool breeds (Merino, Afrino and Dormer), can be tanned successfully with the wool on. Skins from Speckled Persians yield very attractive wool on tanned skins.

Physical tests

The physical test results are summarised in Table 1 for leather produced from skins of the ten breeds. From the Table it is evident that Merino leather performed significantly poorer than most of the other breeds, while Damara leather was significantly stronger than some of the other breeds tested. Afrino leather was significantly stronger, could be extended more before the grain cracks and a higher force was required to tear the leather in the slit tear strength test compared to Merino leather. Furthermore, Afrino leather did not differ significantly from that of any of the other breeds tested and were more comparable with leather produced from Persian and Dormer skins than Merino skins as far as the physical tests are concerned. The appearance of small ribs on some of the Afrino skins would, however, offset the superior physical leather properties. As there is a large variation within the Afrino breed with regard to the extent of ribbiness of the skin, it would be difficult in practice to classify Afrino skins separate from Merino skins, as it is not always possible to observe small ribs from the flesh side of raw skins. 
Short paper and poster abstracts: $38^{\text {th }}$ Congress of the South African Society of Animal Science

Table 1 Physical test results (SE) of leather produced from different sheep skins

\begin{tabular}{|c|c|c|c|c|c|}
\hline Breed & $\begin{array}{l}\text { Tensile } \\
\text { strength } \\
(\mathrm{Mpa}) \\
\end{array}$ & $\begin{array}{l}\text { Extension at } \\
\text { grain Crack } \\
(\%)\end{array}$ & $\begin{array}{l}\text { Extension at } \\
\text { grain Break }(\%)\end{array}$ & $\begin{array}{l}\text { Slit tear } \\
\text { strength } \\
(\mathrm{N} / \mathrm{mm})\end{array}$ & $\begin{array}{l}\text { Lastometer } \\
(\mathrm{nm})\end{array}$ \\
\hline \multirow[t]{2}{*}{ Afrino (a) } & 18.13 & 62.33 & $74.67^{f}$ & $53.20^{f}$ & 12.40 \\
\hline & $(2.55)$ & $(7.27)$ & $(6.66)$ & (4.19) & $(0.48)$ \\
\hline \multirow[t]{2}{*}{ Damara (b) } & $22.56^{\mathrm{d}, \mathrm{e}, \mathrm{f}}$ & $80.60^{\mathrm{e}, \mathrm{f}, \mathrm{g}, \mathrm{i}}$ & $89.00^{\mathrm{f}, \mathrm{g}, \mathrm{h}, \mathrm{j}}$ & 44.98 & 12.14 \\
\hline & (1.98) & $(5.63)$ & $(5.16)$ & (3.24) & $(0.37)$ \\
\hline \multirow{2}{*}{$\begin{array}{l}\text { Hair Dorper } \\
\text { (c) }\end{array}$} & $18.72^{f}$ & $70.20^{f}$ & $82.20^{\mathrm{f}, \mathrm{g}}$ & $47.24^{f}$ & $11.52^{\mathrm{f,i}, \mathrm{j}}$ \\
\hline & (1.98) & $(5.63)$ & $(5.16)$ & $(3.24)$ & $(0.37)$ \\
\hline \multirow{2}{*}{$\begin{array}{l}\text { Wool Dorper } \\
\text { (d) }\end{array}$} & $14.84^{\mathrm{b}, \mathrm{h}, \mathrm{i}, \mathrm{j}}$ & $72.80^{f}$ & $83.00^{f, g}$ & 43.22 & $11.62^{\mathrm{f,i}, \mathrm{j}}$ \\
\hline & (1.98) & $(5.63)$ & $(5.16)$ & $(3.24)$ & $(0.37)$ \\
\hline \multirow[t]{2}{*}{ Dormer (e) } & $12.85^{\mathrm{b}, \mathrm{g}, \mathrm{h}, \mathrm{i}, \mathrm{j}}$ & $60.50^{\mathrm{b}}$ & $75.50^{f}$ & $47.85^{f}$ & $11.80^{\mathrm{f}, \mathrm{i}}$ \\
\hline & $(2.21)$ & $(6.30)$ & $(5.77)$ & (3.62) & $(0.42)$ \\
\hline \multirow[t]{2}{*}{ Merino (f) } & $11.86^{\mathrm{b}, \mathrm{c}, \mathrm{g}, \mathrm{h}, \mathrm{i}, \mathrm{j}}$ & $44.20^{\mathrm{b}, \mathrm{c}, \mathrm{d}, \mathrm{h}, \mathrm{i}, \mathrm{j}}$ & $54.00^{\mathrm{a}, \mathrm{b}, \mathrm{c}, \mathrm{d}, \mathrm{e}, \mathrm{h}, \mathrm{i}, \mathrm{j}}$ & $37.62^{\mathrm{a}, \mathrm{c}, \mathrm{e}, \mathrm{j}}$ & $13.12^{\mathrm{c}, \mathrm{d}, \mathrm{e}}$ \\
\hline & $(1.98)$ & $(5.63)$ & $(5.16)$ & $(3.24)$ & $(0.37)$ \\
\hline Namaqua & $19.44^{\mathrm{e}, \mathrm{f}}$ & $57.00^{b}$ & $66.20^{b, c, d}$ & 45.14 & 12.12 \\
\hline Afrikaner (g) & (1.98) & $(5.63)$ & $(5.16)$ & (3.24) & $(0.37)$ \\
\hline Blackhead & $20.86^{\mathrm{d}, \mathrm{e}, \mathrm{f}}$ & $65.40^{f}$ & $74.20^{\mathrm{b}, \mathrm{f}}$ & 42.54 & 12.44 \\
\hline Persian (h) & $(1.98)$ & $(5.63)$ & $(5.16)$ & $(3.24)$ & $(0.37)$ \\
\hline Speckled & $21.34^{\mathrm{d}, \mathrm{e}, \mathrm{f}}$ & $63.60^{\mathrm{b}, \mathrm{f}}$ & $77.20^{f}$ & 44.70 & $13.10^{\mathrm{c}, \mathrm{d}, \mathrm{e}}$ \\
\hline Persian (i) & (1.98) & $(5.63)$ & $(5.16)$ & $(3.24)$ & $(0.37)$ \\
\hline \multirow[t]{2}{*}{ Van Rooy (j) } & $21.18^{\mathrm{d}, \mathrm{e}, \mathrm{f}}$ & $67.60^{f}$ & $72.60^{\mathrm{b}, \mathrm{f}}$ & $47.86^{f}$ & $12.74^{\mathrm{c}, \mathrm{d}}$ \\
\hline & (1.98) & $(5.63)$ & $(5.16)$ & (3.24) & $(0.37)$ \\
\hline \multirow[t]{2}{*}{ Average } & 18.18 & 64.42 & 74.86 & 45.44 & 12.30 \\
\hline & $(0.65)$ & $(1.86)$ & $(1.71)$ & (1.07) & $(0.12)$ \\
\hline
\end{tabular}

\section{Conclusion}

From the results of this study it is evident that, with the exception of Merino skins, there is very little difference among breeds with regard to the quality of the leather produced from their skins. Skins from all these breeds, again with the exception of Merino skins, are well suited to be processed into clothing leather. The lack of sufficient numbers of skins from Damara, Namaqua, Van Rooy and Persian sheep, contribute to the fact that Dorper skins are the most popular and sought after in the industry. It is further obvious that the practice of classifying Afrino skins as Merino skins, is not correct. A viable and practical method of identifying and classing Afrino skins separate from Merino skins in the industry, should be investigated. 